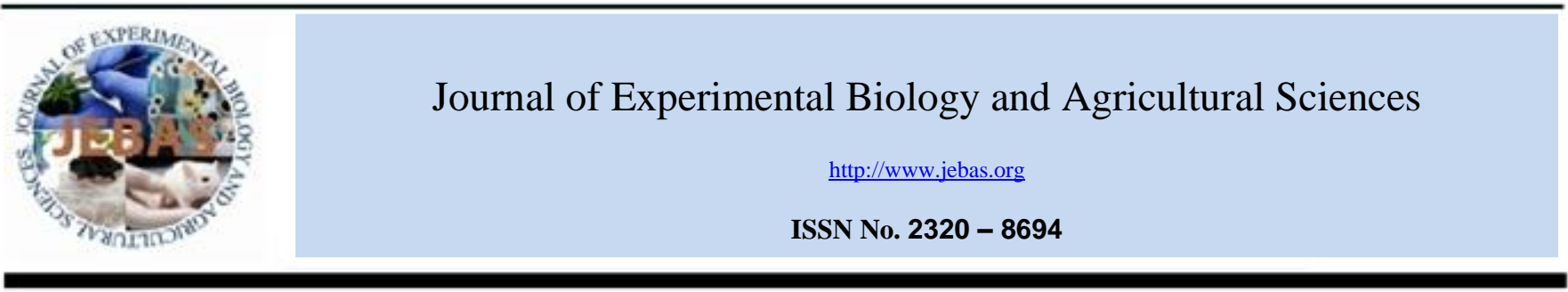

\title{
BIOCHEMICAL AND PHYSIOLOGICAL ANALYSIS OF ZINC TOLERANCE IN Jatropha curcas
}

\author{
Preeti Badoni ${ }^{1}$, Maya Kumari ${ }^{2}$, Vikas Yadav Patade ${ }^{3}$, Atul Grover ${ }^{1,{ }^{*}}$ and M Nasim ${ }^{1}$ \\ ${ }^{1}$ Defence Institute of Bio-Energy Research (DIBER), Goraparao, P.O. Arjunpur, Haldwani 263139. India \\ ${ }^{2}$ Office of Director General Life Sciences, Defence Research and Development Organization, DRDO Bhawan, Rajaji Marg, New Delhi 110011. India \\ ${ }^{3}$ Defence Institute of Bio-Energy Research (DIBER) Field Station, Panda Farm, Pithoragarh 262501. India
}

Received - October 01, 2015; Revision - October 21, 2015; Accepted - January 27, 2016

Available Online - February 15, 2016

DOI: http://dx.doi.org/10.18006/2015.4(1).07.15

\section{KEYWORDS}

Antioxidant enzymes

Growth parameters

Lipid peroxidation

Proline content

Zinc accumulation

\begin{abstract}
Jatropha curcas L., widely recognized as a viable option for production of bio diesel, has been assessed for its ability to withstand stress induced by supra-optimal zinc concentrations. In the present study plants were exposed to varying Zinc (Zn) concentrations (0, 500, 1000, 1500 and $2000 \mathrm{mg} / \mathrm{kg}$ ), and and different growth, physiological and biochemical parameters were studied. It was reported that up to $1500 \mathrm{mg} / \mathrm{kg} \mathrm{Zn}$, no significant effects on most of the growth parameters of the plants could be seen. However at $2000 \mathrm{mg} / \mathrm{kg} \mathrm{Zn}$, a clear retardation of growth was visible, which was apparently reflected by the physiological as well as biochemical parameters. These effects were more profound in the aerial parts of the plant. Atomic Absorption Spectra (AAS) profiles suggested that Zn got mainly accumulated in the roots after absorption from the soil. Osmotic adjustments indicated significantly increased accumulation of proline, phenols and reducing sugars with increasing concentration of $\mathrm{Zn}$ as compared to the control. Membrane damage was not observed up to $1000 \mathrm{mg} / \mathrm{kg}$ concentration. Jatropha, owing to its tolerance to supra-optimal $\mathrm{Zn}$ concentrations is, thus, a suitable candidate for phytoremediation of $\mathrm{Zn}$ from contaminated soils along with cultivation for biofuel production.
\end{abstract}

* Corresponding author

E-mail: iatulgrover@gmail.com (Atul Grover)

Peer review under responsibility of Journal of Experimental Biology and Agricultural Sciences.

Production and Hosting by Horizon Publisher (http://publisher.jebas.org/index.html).

All rights reserved.
All the article published by Journal of Experimental Biology and Agricultural Sciences is licensed under a Creative Commons Attribution-NonCommercial 4.0 International License Based on a work at www.jebas.org.

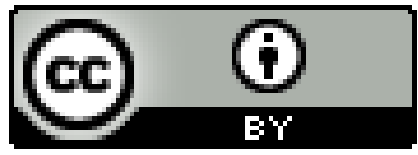




\section{Introduction}

Heavy metals (HMs), frequently referred to lead $(\mathrm{Pb})$, chromium (Cr), arsenic (As), zinc (Zn), cadmium (Cd), copper $(\mathrm{Cu})$, mercury $(\mathrm{Hg})$ and nickel $(\mathrm{Ni})$ occur naturally in the soils. Beyond a certain concentration, these heavy metals are toxic. In recent years, their concentrations in soil have become a concern worldwide (Rascio \& Navari-Izzo, 2011; Villiers et al., 2011). $\mathrm{Zn}$ is a necessary cofactor for many biological reactions, known to limit oxidative degradation of auxin and is necessary to maintain membrane integrity (Tsonev \& Lidon, 2012). Zinc concentration in soils lesser than $125 \mathrm{ppm}$ is considered optimum for the growth of plants (Hussain et al., 2010). Plants growing in such edaphic environments display $\mathrm{Zn}$ concentrations in the range $0.02-0.04 \mathrm{mg} \mathrm{g}^{-1}$ dry weight (Tsonev \& Lidon, 2012). Higher concentrations of $\mathrm{Zn}$ in soil, however, have direct effects on the growth and yields of the plants (Chibuike \& Obiora, 2014), and thus adversely affect the agriculture.

The general symptoms are stunting of shoot, curling and rolling of young leaves, death of leaf tips (Rout \& Das, 2003) and chlorosis (Rout \& Das, 2003). Due to Zn toxicity, the activity of proteins present in the plasma membrane and especially the activity of SH groups gets affected which causes damage to membrane stability. As soon as heavy metals pass through the plasma membrane, they can immediately interact with all metabolic processes (Rout \& Das, 2003). To avoid Zn toxicity in plants, the excess quantities of $\mathrm{Zn}$ shall be cleaned up from the soil. Among several methods available for such clean up, phytoremediation is catching attention in recent years, as plants survive for longer durations and have potential to permanently fix the pollutants. Plants have many cellular mechanisms involved in the detoxification of heavy metals and thus tolerance to metal stress. These include the binding of metals to cell wall and extracellular exudates, reduced uptake or efflux pumping of metals at the plasma membrane, chelation of metals in the cytosol by peptides such as phytochelatins, repair of stress-damaged proteins and the compartmentation of metals in the vacuole by tonoplast located transporters (Hall, 2002). However, this necessitates that plants being used for phyto-remediation should be non-edible and can grow effectively at the polluted sites (Nanda \& Abraham, 2011).

In view of the above, we have assessed the potential of jatropha, which is also being projected as a promising bio fuel crop, to survive and thrive under condition of higher soil concentrations of $\mathrm{Zn}$. It is a small tree that has naturalized in most parts of the world and grows in a variety of agro-climatic areas. Many studies show the potential of J. curcas to recover and reclaim heavy metal contaminated soil (Yadav et al., 2009).

\section{Materials \& Methods}

2.1 Plant material and $\mathrm{Zn}$ concentrations
Mature, healthy and current harvest seeds of $J$. curcas strain DARL-2 were soaked overnight in $0.1 \%$ (w/v) Bavistin, washed several times under running tap before sterilizing with $70 \%$ (v/v) ethanol and followed by three washes of sterile water. Thereafter, seeds were allowed to germinate on moist filter papers in Petri dishes. After germination, seedlings of uniform size were selected and transplanted into pots containing autoclaved mixture of sand and soil in 1:1 ratio. $\mathrm{ZnSO}_{4} .5 \mathrm{H}_{2} \mathrm{O}$ solution was added in the pots to obtain the $\mathrm{Zn}^{+2}$ concentrations of 0 (control), 500,1000,1500, $2000 \mathrm{mg} / \mathrm{kg}$ of soils. Experiment was conducted with three replicates each, and replication had five pots having three plants each. Both control and treated pots were irrigated at regular interval.

The $\mathrm{Zn}$ concentration in soil and in different parts of the plant (root, stem and leaf) was estimated using Atomic Absorption Spectrometer (M Series 650294v129, Thermo Electron Corporation, USA) fitted with an air-acetylene burner, expressed as $\mathrm{mg} / \mathrm{g}$ dry weight of the sample.

\subsection{Growth parameters}

Root length, shoot length, total number of leaves, fresh weight and dry weight of root and stem were recorded for each treatment after 4 months.

\subsection{Physiological parameters}

Total chlorophyll $(\mathrm{a}+\mathrm{b})$ and carotenoids were determined from fresh leaf (100 mg FW) according to Arnon (1949). The leaf material was ground in a pre-chilled mortar in acetone $(80 \% \mathrm{v} / \mathrm{v})$. After homogenization, the mixture was filtered and the volume was adjusted to $10 \mathrm{ml}$ with cold acetone. The absorbance of the extract was measured at 645,663 , and 470 $\mathrm{nm}$ using a spectrophotometer (UV-Vis Dual Beam, Labomed inc.) and the pigments content were calculated. The chlorophyll stability indices (CSI) were determined using the formula:

Total chlorophyll content in stressed leaves / total chlorophyll content in control leaves X 100

The leaf relative water content (RWC) was determined according to Patade et al. (2011). Fresh weight (FW) of the leaf was recorded immediately after plucking from the plant. After $24 \mathrm{~h}$ of saturation with deionized water the turgid weight (TW) was recorded. Dry weight (DW) was recorded after drying the leaves for $48 \mathrm{hrs}$ in the hot air oven at $70^{\circ} \mathrm{C}$. The RWC was calculated as:

\section{RWC $(\%)=[($ FW-DW $) /($ TW-DW $)]$ X100}

Reducing sugar was estimated as described by Miller (1959). About $100 \mathrm{mg}$ leaf sample was homogenized in $3 \mathrm{ml}$ of $80 \%$ ethanol. The homogenate was centrifuged at $6000 \mathrm{~g}$ for $10 \mathrm{~min}$ at $48^{\circ} \mathrm{C}$ and the supernatant was mixed with equal volume of 3 , 5-dinitro-salicylic acid (DNSA) reagent. Distilled water was 
vortexing and the tubes were placed in a boiling water bath for 10 min after which they were cooled on ice. The absorbance was measured at $540 \mathrm{~nm}$ and the reducing sugars content (mg $\mathrm{g}^{-1} \mathrm{FW}$ ) was calculated based on standard curve with glucose as standard.

Leaf pieces $\left(\sim 1.0 \mathrm{~cm}^{2}\right)$ after washing with distilled water were transferred to glass culture tubes containing $20 \mathrm{ml}$ distilled water and incubated for $24 \mathrm{~h}$ with intermittent shaking. Electric conductivity was recorded using EC meter (WTW, Germany). $\mathrm{EC}_{1}$ was recorded after $24 \mathrm{hrs}$ of incubation of the leaf. Tubes were capped and then autoclaved at $121^{\circ} \mathrm{C}$ for $20 \mathrm{~min}$. to completely kill the tissues and release all electrolytes. $\mathrm{EC}_{2}$ was recorded after cooling the solution to room temperature. Membrane damage rate (MDR) was calculated using the formula (Lutts et al., 1995):

\section{$\operatorname{MDR}(\%)=\left(\mathrm{EC}_{1} / \mathrm{EC}_{2}\right) \times 100$}

Proline content was determined according to Bates et al. (1973). $200 \mathrm{mg}$ of leaf was homogenized in aqueous sulfosalicylic acid $(3 \% \mathrm{w} / \mathrm{v})$. The filtered homogenate was reacted with equal volume each of acid ninhydrin and acetic acid for $1 \mathrm{~h}$ at $100^{\circ} \mathrm{C}$ in a water bath. The reaction mixture was extracted with toluene and the absorbance was recorded at 520 $\mathrm{nm}$ using toluene as a blank. Proline concentration $\left(\mu \mathrm{g} \mathrm{g}^{-1} \mathrm{FW}\right)$ was determined from a standard curve using L-proline as a standard.

Lipid peroxidation was determined according to the method of Heath \& Packer (1968). $100 \mathrm{mg}$ of leaf was homogenized in $1.5 \mathrm{ml}$ of $0.25 \%$ Thiobarbituric acid (TBA) in $10 \%$ Trichloroacetic acid (TCA). The mixture was heated at $95^{\circ} \mathrm{C}$ for $30 \mathrm{~min}$. and then cooled in ice, it was then centrifuged at $10000 \mathrm{~g}$ for $10 \mathrm{~min}$. Absorbance of the supernatant was read at $532 \mathrm{~nm}$ and $600 \mathrm{~nm}$, keeping $0.25 \%$ TBA in $10 \%$ TCA as blank. MDA content was calculated according to its extinction coefficient of $155 \mathrm{mM}^{-1} \mathrm{~cm}^{-1}$.

Total phenolic content was estimated according to FolinCioalteu method as described by Ainsworth \& Gillespie (2007). The leaf tissue was ground to a fine powder using liquid nitrogen. $2 \mathrm{ml}$ of $95 \%(\mathrm{v} / \mathrm{v}$ ) ice cold methanol was then added to the ground tissue and incubated for $48 \mathrm{~h}$ at room temperature in dark. It was then centrifuged at $13000 \mathrm{~g}$ for 5 min. Supernatant $(100 \mu \mathrm{l})$ was taken and mixed with $200 \mu \mathrm{l}$ of $10 \%(\mathrm{v} / \mathrm{v}) \mathrm{F}-\mathrm{C}$ reagent to which, $800 \mu \mathrm{l}$ of $700 \mathrm{mM} \mathrm{Na} \mathrm{CO}_{3}$ was added and again incubated at room temperature for $2 \mathrm{~h}$. Absorbance was recorded at $765 \mathrm{~nm}$. Total phenolic content was calculated based on standard curve with gallic acid as standard and expressed as $\mathrm{mM} \mu \mathrm{M}^{-1}$ gallic acid equivalent.

\subsection{Antioxidant enzyme assays}

CAT activity was measured in a reaction mixture $(1.0 \mathrm{ml})$ containing $50 \mathrm{mM}$ phosphate buffer $(\mathrm{pH} 7.0)$ and $15 \mathrm{mM} \mathrm{H}_{2} \mathrm{O}_{2}$ initiated by adding $50 \mu \mathrm{l}$ enzyme extract and the activity was determined by monitoring decrease in absorbance at $240 \mathrm{~nm}$ (E $=39.4 \mathrm{mM}^{-1} \mathrm{~cm}^{-1}$ ) for $2 \mathrm{~min}$. at intervals of $15 \mathrm{sec}$, as a result of $\mathrm{H}_{2} \mathrm{O}_{2}$ decomposition. The slope of the rate assay $(\Delta \mathrm{A})$ was used to determine the enzyme activity, which was expressed as $\mu$ mol.mg protein ${ }^{-1} \min ^{-1}$.

APX activity was determined according to Nakano \& Asada (1981). The reaction mixture $(2.0 \mathrm{ml})$ contained $50 \mathrm{mM}$ phosphate buffer ( $\mathrm{pH} 7.0$ ), $0.5 \mathrm{mM}$ ascorbate, $0.1 \mathrm{mM} \mathrm{H} \mathrm{H}_{2} \mathrm{O}_{2}$ and $0.1 \mathrm{mM}$ EDTA. The reaction was started by adding $100 \mu \mathrm{l}$ of crude enzyme. The $\mathrm{H}_{2} \mathrm{O}_{2}$ dependent oxidation of ascorbate was followed by a decrease in the absorbance at $290 \mathrm{~nm}(\mathrm{E}=$ 2.8 $\mathrm{Mm}^{-1} \mathrm{~cm}^{-1}$ ). APX activity was measured in terms of $\mu$ mol.mg protein ${ }^{-1} \min ^{-1}$.

GPX activity was determined according to Kar \& Feierabend (1984). The reaction mixture $(1.0 \mathrm{ml})$ contained $50 \mathrm{mM}$ phosphate buffer (pH 7.0), 0.1 mM EDTA, $10 \mathrm{mM}$ guiacol and $10 \mathrm{mM} \mathrm{H}_{2} \mathrm{O}_{2}$. Oxidation of guiacol was monitored by measuring the increase in absorbance at $470 \mathrm{~nm}\left(\mathrm{E}=26.6 \mathrm{Mm}^{-}\right.$ ${ }^{1} \mathrm{~cm}^{-1}$ ) for $1 \mathrm{~min}$ at interval of $15 \mathrm{~s}$ after addition of $50 \mu 1$ of crude enzyme. GPX activity was measured in terms of $\mu \mathrm{mol}$ of tetraguaicol formed $\mathrm{mg}$ protein ${ }^{-1} \mathrm{~min}^{-1}$.

\subsection{Statistical Analysis}

Mean, standard error and statistical significance of mean values for different parameters were determined. Analysis of variance (ANOVA) for all the variables was performed using Cropstat for Windows (7.2.2007.2 module, IRRI, Phillipines).

\section{Results}

\subsection{Growth responses}

Compared to the control, the growth parameters were not significantly ( $p>0.05$ ) affected up to $1500 \mathrm{mg} / \mathrm{kg} \mathrm{Zn}$ (Table 1) as seen by non-significant differences in various growth parameters (root length, shoot length, fresh and dry weight of the root and fresh and dry weight of the stem). However, at $2000 \mathrm{mg} / \mathrm{kg} \mathrm{Zn}$ all the growth parameters were significantly $(p<0.05)$ reduced except the root length as compared to the control (Table 1).

\section{2 $\mathrm{Zn}$ accumulation in different plant parts}

A significant amount of $\mathrm{Zn}$ was detected in $J$. curcas plants grown at different concentrations of metal. Accumulation was maximum in the roots, i.e., $8.93 \mathrm{mg} / \mathrm{g}$ DW followed by the stem $3.61 \mathrm{mg} / \mathrm{g}$ DW and leaves $0.79 \mathrm{mg} / \mathrm{g}$ DW (Figure 1). About nine folds higher $\mathrm{Zn}$ level was detected in the roots at $2000 \mathrm{mg} / \mathrm{kg} \mathrm{Zn}$ as compared to the control. Similarly the level of $\mathrm{Zn}$ in the stem and leaves of plants at $2000 \mathrm{mg} / \mathrm{kg} \mathrm{Zn}$ was 11.5 folds and 1.27 folds respectively in relation to the control. 
Table 1 Effect of different concentrations of Zn on growth parameters of $J$. curcas. Standard error of three treatment means (SE) and LSD values are given in the last row.

\begin{tabular}{|lccccccc|}
\hline $\begin{array}{l}\text { Zn conc. } \\
(\mathrm{mg} / \mathrm{kg} \text { soil) }\end{array}$ & $\begin{array}{c}\text { Root length } \\
(\mathrm{cm})\end{array}$ & $\begin{array}{c}\text { Shoot length } \\
(\mathrm{cm})\end{array}$ & $\begin{array}{c}\text { Total } \\
\text { leaves }\end{array}$ & $\begin{array}{c}\text { Fresh weight } \\
\text { stem }(\mathrm{g})\end{array}$ & $\begin{array}{c}\text { Dry weight } \\
\text { stem }(\mathrm{g})\end{array}$ & $\begin{array}{c}\text { Fresh weight } \\
\text { Root }(\mathrm{g})\end{array}$ & $\begin{array}{c}\text { Dry weight } \\
\text { Root }(\mathrm{g})\end{array}$ \\
\hline 0 & 8.233 & 21.767 & 9.000 & 3.625 & 2.493 & 0.270 & 0.056 \\
\hline 500 & 8.483 & 22.333 & 8.33 & 3.785 & 2.690 & $0.467^{*}$ & $0.072^{*}$ \\
\hline 1000 & 7.050 & 20.833 & 9.00 & 3.699 & 2.462 & $0.330^{*}$ & $0.063^{*}$ \\
\hline 1500 & 5.267 & 20.733 & $10.67^{*}$ & 3.277 & 2.570 & 0.234 & 0.053 \\
\hline 2000 & 4.583 & $14.600^{*}$ & 8.00 & $1.778^{*}$ & $1.398^{*}$ & $0.161^{*}$ & $0.024^{*}$ \\
\hline SE & 0.778 & 0.293 & 0.24 & 0.128 & 0.093 & 0.013 & 0.001 \\
\hline 5\% LSD & 2.295 & 0.956 & 0.77 & 0.418 & 0.303 & 0.039 & 0.005 \\
\hline
\end{tabular}

The values marked with asterisk (*) are significantly different from control at $\mathrm{P} \leq 0.05$, as determined using Least Significant Difference (LSD) test.

3.3 $\mathrm{Zn}$ concentration in soil before planting and after harvesting of $J$. curcas

The results of soil analysis showed that the percent uptake of $\mathrm{Zn}$ increased significantly $(p<0.05)$ at different concentrations as compared to the control (Table 2). At $2000 \mathrm{mg} / \mathrm{kg} \mathrm{Zn}$ concentration, the percentage uptake of $\mathrm{Zn}$ from soil increased by 6.68 folds as compared to the control.

\subsection{Chlorophyll and carotenoid contents}

The total chlorophyll and carotenoides contents, and the chlorophyll stability index was increased significantly $(p<0.05)$ at $1000 \mathrm{mg} / \mathrm{kg} \mathrm{Zn}$ as compared to the control but at lower (500 $\mathrm{mg} / \mathrm{kg}$ ) and higher ( $\geq 1500 \mathrm{mg} / \mathrm{kg}$ ) concentrations of $\mathrm{Zn}$, no difference in the total chlorophyll content and the chlorophyll stability index were observed (Table 3).

\subsection{Osmotic adjustments}

In response to different concentrations of $\mathrm{Zn}$, RWC of the leaf was not significantly $(p>0.05)$ changed as compared to the control, but the accumulation of reducing sugars has significantly $(p<0.05)$ increased in relation to the control. Significantly $(p<0.05)$ higher content of total phenol $(1.44$ folds) and proline ( 2 folds) was observed at $2000 \mathrm{mg} / \mathrm{kg} \mathrm{Zn}$ as compared to the control (Figure $2 \mathrm{a} \& \mathrm{~b}$ ).

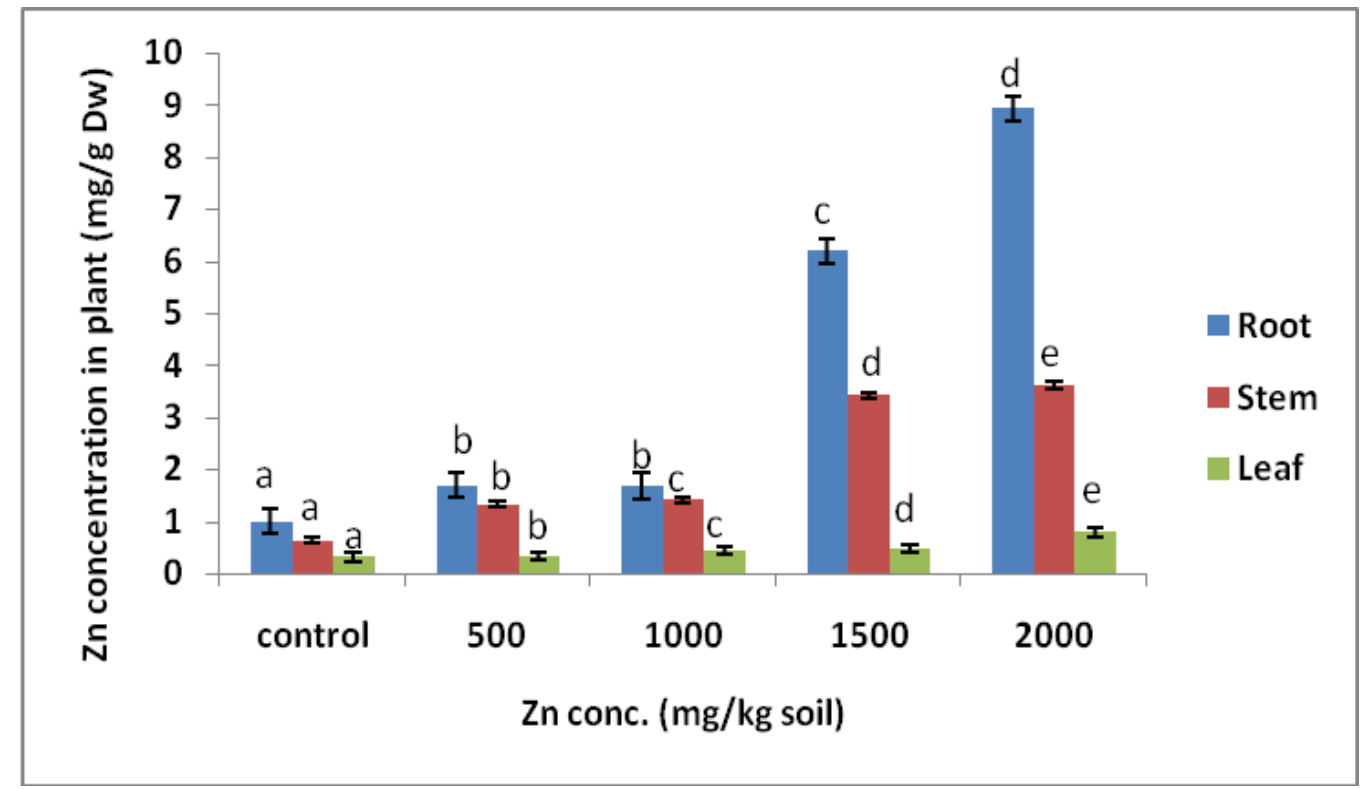

Figure 1 Accumulation of $\mathrm{Zn}$ in plant parts exposed to different concentrations of $\mathrm{Zn}$. Different letters indicate significant differences at p>0.05, as determined using Least Significant Difference (LSD) test. Error bars indicate SE of three treatment means. 


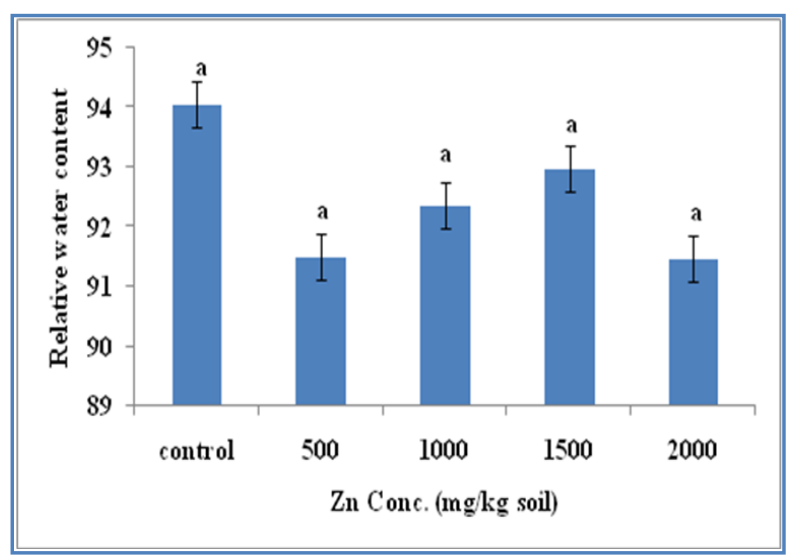

Figure 2a Effects of different concentrations of $\mathrm{Zn}$ on RWC measured in leaves of $J$. curcas. Different letters indicate significant differences at $\mathrm{p}>0.05$, as determined using Least Significant Difference (LSD) test. Error bars indicate SE of three treatment means.

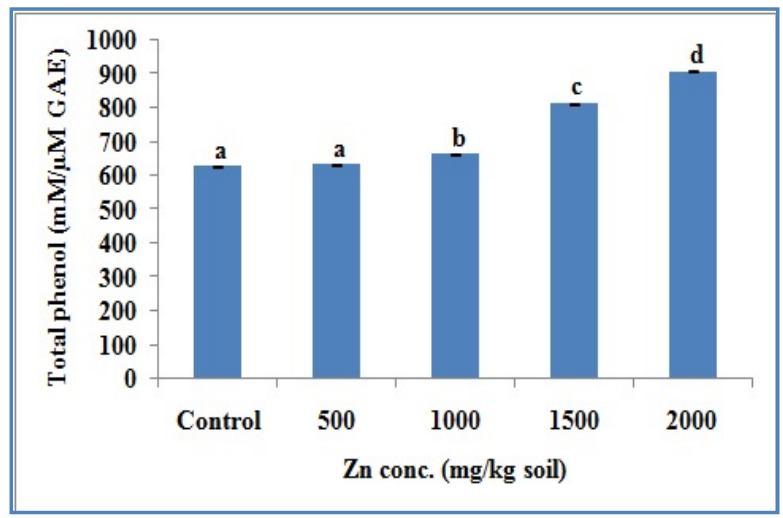

Figure 2c Effects of different concentrations of $\mathrm{Zn}$ on total phenol measured in leaves of $J$. curcas. Different letters indicate significant differences at $\mathrm{p}>0.05$, as determined using Least Significant Difference (LSD) test. Error bars indicate SE of three treatment means.

3.6 Lipid peroxidation and Membrane damage rate

Higher concentrations of $\mathrm{Zn}$ has affected the membrane properties which is revealed by significantly $(p<0.05)$ increased (1.31 folds) amount of MDA content at $2000 \mathrm{mg} / \mathrm{kg}$ $\mathrm{Zn}$ as compared to the control (Figure 3a). However, the electrical conductivity of the leaves was not significantly ( $p>0.05)$ changed in response to higher $\mathrm{Zn}$ concentrations as compared to the control (Figure $3 b$ ).

3.7 Antioxidant enzyme activities

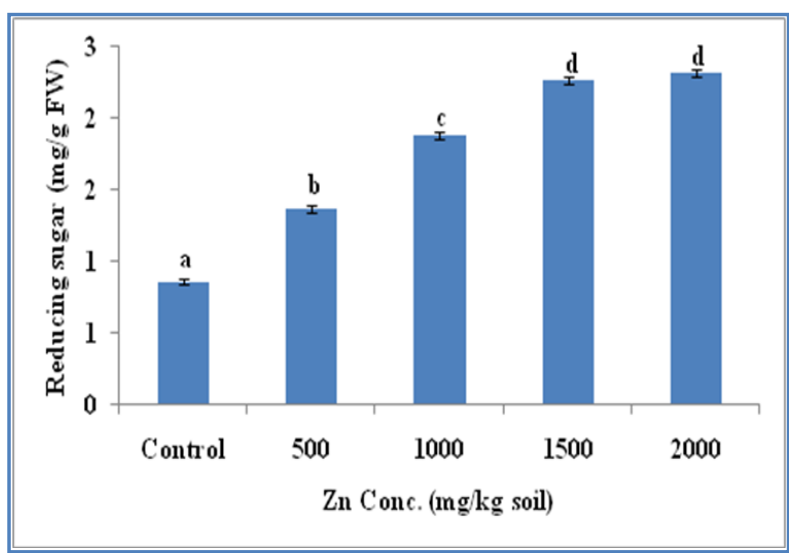

Figure $2 b$ Effects of different concentrations of $\mathrm{Zn}$ on reducing sugar measured in leaves of $J$. curcas. Different letters indicate significant differences at $p>0.05$, as determined using Least Significant Difference (LSD) test. Error bars indicate SE of three treatment means.

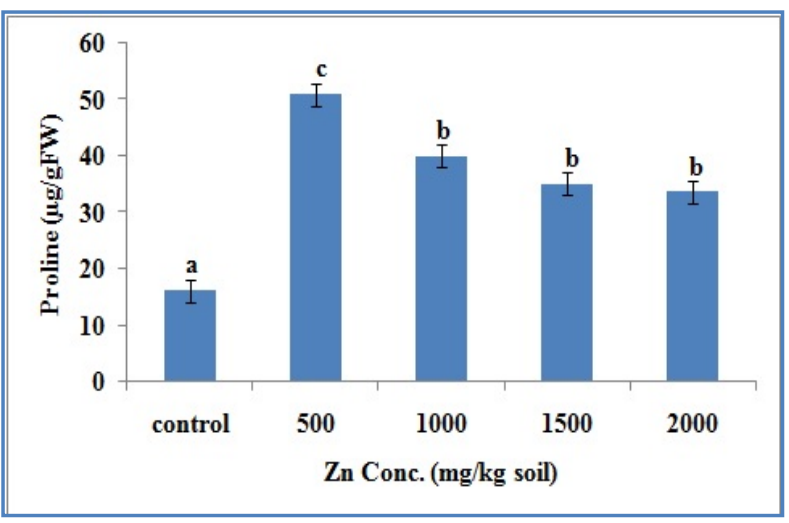

Figure 2d Effects of different concentrations of $\mathrm{Zn}$ on proline content measured in leaves of J. curcas. Different letters indicate significant differences at $\mathrm{p}>0.05$, as determined using Least Significant Difference (LSD) test. Error bars indicate SE of three treatment means.

The activities of the antioxidant enzymes (CAT, APX and GPX) were significantly $(p<0.05)$ increased in response to higher concentrations of $\mathrm{Zn}$ as compared to the control (Figure $4 \mathrm{a}-\mathrm{c})$. In relation to the control, significantly $(p \leq 0.05)$ higher CAT activity was observed in all the treatments and the highest increase of 2.8 folds was observed at $1000 \mathrm{mg} / \mathrm{kg} \mathrm{Zn}$. The APX activity was significantly $(p \leq 0.05)$ increased up-to 1500 $\mathrm{mg} / \mathrm{kg} \mathrm{Zn}$ (2.3 folds) but at $2000 \mathrm{mg} / \mathrm{kg} \mathrm{Zn}$ the APX activity was decreased in relation to the control. GPX activity was also significantly $(p \leq 0.05)$ increased in all the treatments in relation to the control and the highest increase of 3.4 folds was observed at $2000 \mathrm{mg} / \mathrm{kg} \mathrm{Zn}$. 
Table 2 Analysis of the soil sample used for growing $J$. curcas exposed to different concentrations of $\mathrm{Zn}$.

\begin{tabular}{|lcc|}
\hline Initial Zn conc. in soil $(\mu \mathrm{g} / \mathrm{g})$ & Final Zn conc. in soil $(\mu \mathrm{g} / \mathrm{g})$ & $\%$ Zn uptake by plant from soil \\
\hline$($ Control $) 12$ & 10.33 & 13.89 \\
\hline 500 & $55.00^{*}$ & $89.00^{*}$ \\
\hline 1000 & $103.00^{*}$ & $89.70^{*}$ \\
\hline 1500 & $112.00^{*}$ & $92.53^{*}$ \\
\hline 2000 & $144.00^{*}$ & $92.80^{*}$ \\
\hline SE & 0.82 & 1.00 \\
\hline LSD $\mathrm{p} \leq 0.05$ & 0.58 & 0.71 \\
\hline
\end{tabular}

The values marked with asterisk (*) are significantly different from control at $\mathrm{P} \leq 0.05$, as determined using Least Significant Difference (LSD) test.

Table 3 Effect of different concentrations of $\mathrm{Zn}$ on pigment content in J. curcas. Standard error of three treatment means (SE) and LSD values are given in the last row.

\begin{tabular}{|llll|}
\hline Zn conc. $(\mathrm{mg} / \mathrm{kg}$ soil $)$ & Chl $(\mathrm{a}+\mathrm{b})(\mathrm{mg} / \mathrm{gFW})$ & Chlorophyll stability index $(\mathrm{CSI})$ & Carotenoids $(\mathrm{mg} / \mathrm{gFW})$ \\
\hline 0 & 8.40 & 100 & 415.56 \\
\hline 500 & 9.16 & 109.06 & 442.47 \\
\hline 1000 & $14.22^{*}$ & $169.33^{*}$ & $633.56^{*}$ \\
\hline 1500 & 9.01 & 107.28 & 483.21 \\
\hline 2000 & 7.99 & 95.06 & 354.70 \\
\hline SE & 0.49 & 5.99 & 18.39 \\
\hline LSD & 1.61 & 19.55 & 59.97 \\
\hline
\end{tabular}

The values marked with asterisk (*) are significantly different from control at $\mathrm{P} \leq 0.05$, as determined using Least Significant Difference (LSD) test.

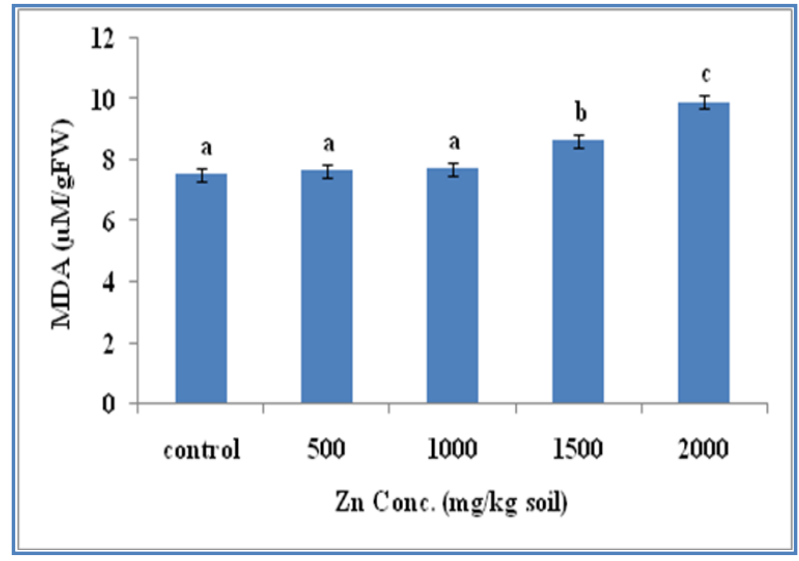

Figure 3a Effects of different concentrations of $\mathrm{Zn}$ on MDA measured in leaves of $J$. curcas. Different letters indicate significant differences at $\mathrm{p}>0.05$, as determined using Least Significant Difference (LSD) test. Error bars indicate SE of three treatment means.

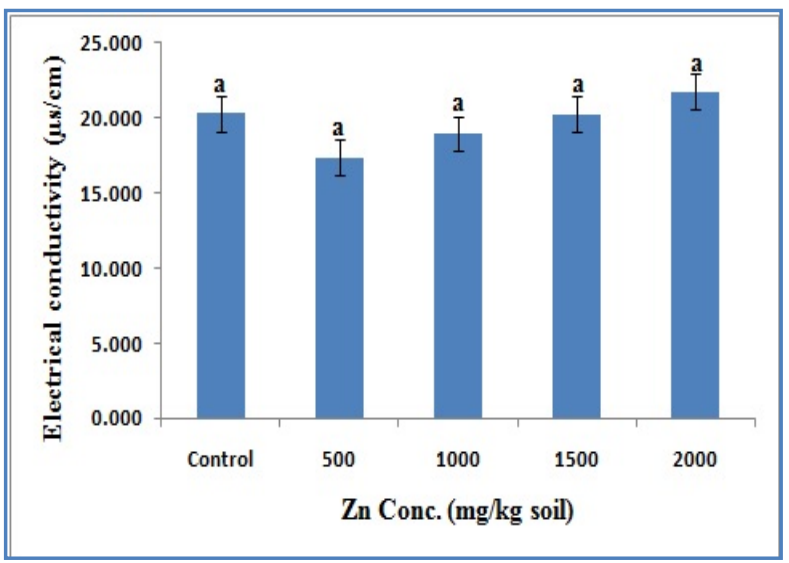

Figure $3 \mathrm{~b}$ Effects of different concentrations of $\mathrm{Zn}$ on EC measured in leaves of J. curcas. Different letters indicate significant differences at $p>0.05$, as determined using Least Significant Difference (LSD) test. Error bars indicate SE of three treatment means. 


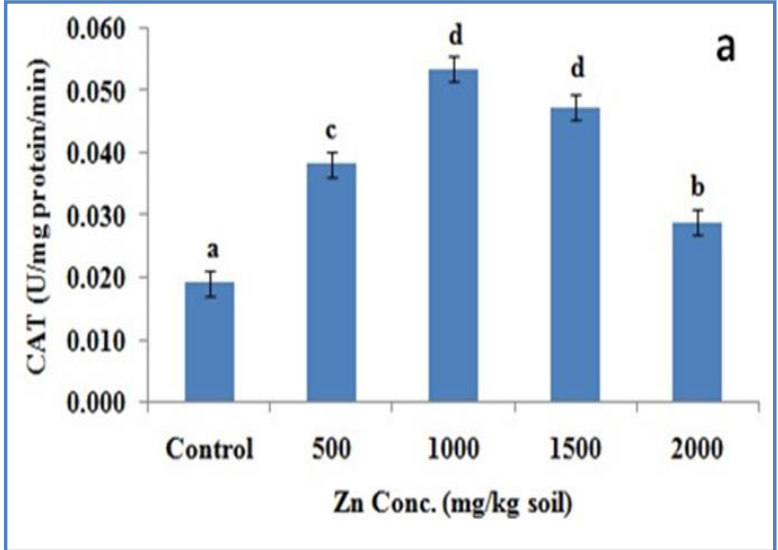

Figure 4a Effects of different concentrations of $\mathrm{Zn}$ on CAT activity measured in leaves of J. curcas. Different letters indicate significant differences at $\mathrm{p}>0.05$, as determined using Least Significant Difference (LSD) test. Error bars indicate SE of three treatment means.

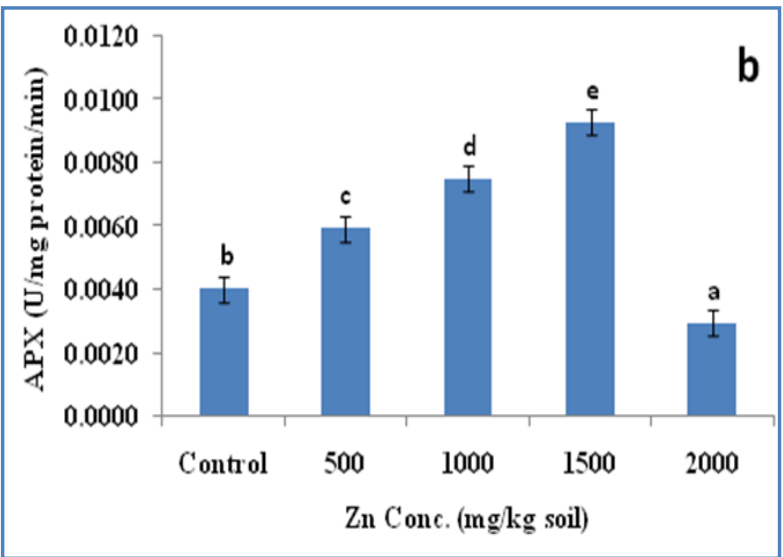

Figure $4 \mathrm{~b}$ Effects of different concentrations of $\mathrm{Zn}$ on APX activity measured in leaves of $J$. curcas. Different letters indicate significant differences at $\mathrm{p}>0.05$, as determined using Least Significant Difference (LSD) test. Error bars indicate SE of three treatment means.

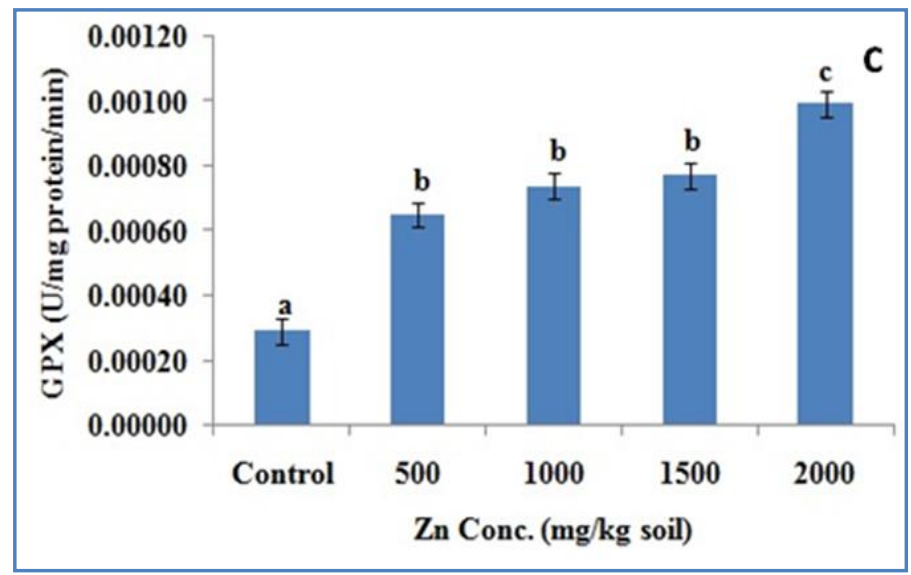

Figure 4c Effects of different concentrations of $\mathrm{Zn}$ on GPX activity measured in leaves of $J$. curcas. Different letters indicate significant differences at p>0.05, as determined using Least Significant Difference (LSD) test. Error bars indicate SE of three treatment means.

\section{Discussion}

Despite being an essential micronutrient, the threshold of toxicity due to $\mathrm{Zn}$ varies among plant species (Tsonev \& Lidon, 2012). J. curcas, has remarkable ability to withstand elevated levels of $\mathrm{Zn}$ concentration, often accumulating excess concentrations within the cells. It was reported that shoot length, total number of leaves, fresh weight of stem, fresh weight of root, dry weight of stem and dry weight of root were not affected up to $1500 \mathrm{mg} / \mathrm{kg} \mathrm{Zn}$. At $2000 \mathrm{mg} / \mathrm{kg} \mathrm{Zn}$, however, a significant decrease in the growth parameters was observed, though no significant reductions occurred in the root length. Growth inhibition is a general phenomenon associated with most of heavy metals (Luo et al., 2010) and there are reports which show that higher $\mathrm{Zn}$ concentrations results in biomass decline and inhibition of cell elongation and division (Tsonev \& Lidon, 2012).

$\mathrm{Zn}$ acts as a structural and catalytic component of proteins, enzymes and as a co-factor for normal development of pigment biosynthesis which could be the reason behind increased chlorophyll and carotenoid contents at $1000 \mathrm{mg} / \mathrm{kg} \mathrm{Zn}$ as compared to the control. Chlorophyll pigments are present in the chloroplasts of leaves and it has been found that under stress the amount of chloroplast increases for maintaining the photosynthesis in plants. Increased content of photosynthetic pigments was also observed by other workers (Jamil et al., 
2007; Pinhiero et al., 2008; Rahdari et al., 2012) under different abiotic stresses.

The RWC in Jatropha plants grown at different concentrations of $\mathrm{Zn}$ was not significantly affected as compared to the control, indicating ability of Jatropha to osmotically adjust to higher concentrations (upto $2000 \mathrm{mg} / \mathrm{kg}$ ) of $\mathrm{Zn}$ in soil. Osmotic adjustment was also inferred in terms of levels of accumulation of reducing sugars, phenols and proline in leaf tissues. The accumulation of reducing sugars could be a result of starch degradation, and helps in adjusting water potential in the cytosol, i.e., intracellular osmotic adjustment. In case of accumulation of heavy metals, altered water potential would be instrumental in adjusting to higher concentrations of accumulated ions in the vacuole, and would protect integrity of cellular membranes (Naghavi, 2014).

Proline too is a well documented osmolyte involved in abiotic stress tolerance including heavy metal stress (Chandra et al., 2012; Corcuera et al., 2012; Diaz et al., 2014; Pandey \& Gupta, 2015). Elevated levels of proline during stress conditions could be a result of increased catabolism of the phenolic compounds (Hamid et al., 2010). Importantly, free proline chelates the metal ions, forming non-toxic metalproline complexes, thereby protecting cellular structures, and metabolism thereof (Patel et al., 2013). Results of present study indicated that increase in total phenolic content at higher concentrations of $\mathrm{Zn}$ as compared to the control. Presumably, the oxidative effects of metal ions and metalloids are prevented by the antioxidant activity of phenolics that allows them to scavenge free ions due to their redox properties, thereby showing elevated levels of proline (Hamid et al., 2010). The breakdown of phenolics is triggered by the enzymes and a trailing cascading reactions, what we commonly also refer to as participation of 'antioxidant enzymes', which would involve hydrogen donors and quenchers of reactive oxygen species (ROS). $\mathrm{H}_{2} \mathrm{O}_{2}$ is an important ROS that disrupts the functions of the cell. CAT, APX and GPX are important enzymes that regulate the levels of $\mathrm{H}_{2} \mathrm{O}_{2}$ (Hosseini \& Poorakbar, 2013). We have found an increased activity of CAT, APX and GPX enzymes at different concentrations of $\mathrm{Zn}$ as compared to control suggesting higher abilities of Jatropha to withstand oxidative stress generated by $\mathrm{Zn}$.

From the above discussion, it is inferred that J. curcas can remove a significant amount of $\mathrm{Zn}$ from the soil and roots are the primary sink for accumulation of the metal, causing almost no damage to the plant growth.

\section{Acknowledgements}

Authors thank Dr. Shashi Bala Singh, Director and Dr. Somnath Singh of Defence Institute of Physiology and Allied Sciences (DIPAS), Delhi for allowing access to Atomic absorption spectrometer. Preeti Badoni thanks Defence Research and Development Organization (DRDO) for research fellowship.

\section{Conflict of interest}

Authors would hereby like to declare that there is no conflict of interests that could possibly arise.

\section{References}

Ainsworth EA, Gillespie KM (2007) Estimation of total phenolic content and other oxidation substrates in plant tissues using Folin-Ciocalteu reagent. Nature Protocols 2:875-877. doi:10.1038/nprot.2007.102.

Arnon DI (1949) copper enzymes in isolated chloroplasts. Polyphenoloxidase in Beta vulgaris. Plant Physiology 24:1-15.

Bates LS, Waldren RP, Tears ID (1973) Rapid determination of free proline for water stress studies. Plant Soil 39:205-207.

Chandra RA, Singh M, Shah K. (2012) Effect of water withdrawl on formation of free radical, proline accumulation and activities of antioxidant enzymes in ZAT12-transformed transgenic tomato plants. Plant Physiology and Biochemistry 61:108-114.

Chibuike GU, Obiora SC (2014) Heavy metal polluted soils: Effect on plants and bioremediation methods. Applied and Environmental Soil Science 2014: Article ID 752708. http://dx.doi.org/10.1155/2014/752708.

Corcuera L, Gil-Pelegrin E, Notivol E (2012) Aridity promotes differences in proline and phytohormone levels in Pinus pinaster populations from contrasting environments. Trees 26 : 99-808. doi: 10.1007/s00468-011-0651-x.

Diaz P, Betti M, Garcia-Calderon M, Perez-Delgado CM, Signorelli S, Borsani O, Marquez AJ, Monza J (2014) Amino acids and drought stress in lotus: Use of transcriptomics and plastidic glutamine synthetase mutants for new insights in proline metabolism. In: Anjum NA, Gill SS, Gill R (Eds.) Plant adaptation to environmental change. CAB International, USA. pp 53-67.

Hall JL (2002) Cellular mechanisms for heavy metal detoxification and tolerance. Journal of Experimental Botany 53:1-11. doi: 10.1093/jexbot/53.366.1.

Hamid N, Bukhari N, Jawaid F (2010) Physiological responses of Phaseolus vulgaris to different lead concentrations. Pakistan Journal of Botany 42:239-246.

Heath RL, Packer L (1968) Photoperoxidation in isolated chloroplasts. Archives of Biochemistry and Biophysics 125:189-198. doi:10.1016/0003-9861(68)90654-1.

Hosseini Z, Poorakbar L (2013) Zinc toxicity on antioxidative response in (Zea mays L.) at two different pH. Journal of Stress Physiology \& Biochemistry 9:66-73. 
Hussain S, Maqsood MA, Rahmatullah (2010) Increasing grain zinc and yield of wheat for the developing world: A Review. Emirates Journal of Food and Agriculture 22:326-339 .

Jamil M, Lee DB, Jung K, Ashraf M, Lee SH, Rha ES (2007) Effect of salt stress on germination and early seedling growth of four vegetables species. Journal of Central European Agriculture 7:273-281.

Kar M, Feierabend J (1984) Meatbolism of activated oxygen in detached wheat and rye leaves and its relevance to the initiation of senescence. Planta 160: 385-391. doi: 10.1007/BF00429753.

Luo ZB, He XJ, Chen L, Tang L, Gao S, Chen F (2010) Effects of zinc on growth and antioxidant responses in Jatropha curcas seedlings. International Journal of Agriculture and Biology 12: 119-124.

Lutts S, Kinet JM, Bouharmont J (1995) Changes in plant response to $\mathrm{NaCl}$ during development of rice Oryza sativa $\mathrm{L}$. varieties differing in salinity resistance. Journal of Experimental Botany 46:1843-1852.

Maehly AC (1954) The Assay of Catalases and Peroxidases. In: Glick D(Ed), Methods of Biochemical Analysis, Volume 1 John Wiley \& Sons, Inc., Hoboken, NJ, USA. doi: 10.1002/9780470110171.ch14.

Miller GL (1959) Use of dinitrosalicylic acid reagent for determination of reducing sugars. Analytical Chemistry 31: 426-428.

Naghavi F (2014) Effect of zinc and lead toxicity on some physiological parameters of Glycine max L. Journal of Biodiversity and Environmental Sciences 4:92-201.

Nakano Y, Asada K (1981) Hydrogen peroxide is scavenged by ascorbate-specific peroxidase in spinach chloroplasts. Plant \& Cell Physiology 22:867-880.

Nanda S, Abraham J (2011) Impact of heavy metals on the rhizosphere microflora of Jatropha multifida and their effective remediation. African Journal of Biotechnology 10: 11948-11955.

Pandey C, Gupta M (2015) Selenium and auxin mitigates arsenic stress in rice (Oryza sativa L.) by combining the role of stress indicators, modulators and genotoxicity assay. Journal of Hazardous Materials 287:384-391. doi:10.1016/j.jhazmat.2015.01.044.

Patade VY, Bhargava S, Suprasanna P (2011) Salt and drought tolerance of sugarcane under iso-osmotic salt and water stress: growth, osmolyte accumulation and antioxidant defense. Journal of Plant Interactions 6:275-282.

Patel HV, Parmar SR, Chudasama CJ, Mangrola AV (2013) Interactive studies of zinc with cadmium \& arsenic on seed germination and antioxidant properties of Phaseolus aureus roxb. International Journal of Plant, Animal and Environmental Sciences 3:166-174.

Pinheiroa HA, Silvab JV, Endresc L, Ferreirac VM, Câmarac CA, Cabralc FF, Oliveirac JF, de Carvalhoc LWT, dos Santosc JM, dos Santos Filhod BG (2008) Leaf gas exchange, chloroplastic pigments and dry matter accumulation in castor bean (Ricinus communis L.) seedlings subjected to salt stress conditions. Industrial Crops and Products 27:385-392. doi:10.1016/j.indcrop.2007.10.003.

Rahdari P, Tavakoli S, Hosseini SM (2012) Studying of salinity stress effect on germination, proline, sugar, protein, lipid and chlorophyll content in Purslane (Portulaca oleracea L.) leaves. Journal of Stress Physiology \& Biochemistry 8:182193.

Rascio N, Navari-Izzo F (2011) Heavy metal hyperaccumulating plants: how and why do they do it? And what makes them so interesting? Plant Science 180:169-181. doi:10.1016/j.plantsci.2010.08.016.

Tsonev T, Lidon FJC (2012) Zinc in plants - An overview. Plant Science 24: 322-333.

Villiers F, Ducruix C, Hugouvieux V, Jarno, N, Ezan E, Garin J, Junot C, Bourguignon J (2011) Investigating the plant response to cadmium exposure by proteomic and metabolomic approaches. Proteomics 11:1650-1663.

Yadav SK, Juwarkar AA, Kumar GP, Thawale PR, Singh SK, Chakrabarti T (2009) Bioaccumulation and phyto-translocation of arsenic, chromium and zinc by Jatropha curcas L.: Impact of dairy sludge and biofertilizer. Bioresource Technology 100:4616-4622. 